\title{
Cytological Studies in Three Species of Tolypella
}

\author{
L. Labh ${ }^{1}$ and B. N. Verma
}

1. Department of Botany, Gopeshwar College, Hathwa-841436 (Gopalganj), Bihar India

2. Reader in Botany (Algae), University of Bihar, Muzaffarpur-842001, Bihar, India

Received December 2, 1982

The genus Tolypella Leonh. is among one of the rare members of Charophyta. 12 taxa belonging to this genus have been studied so far from different corners of the world (cf. Lindenbein 1927, Corillion 1960, Hotchkiss, 1963, Sawa 1974 and Guerlesquin 1965, 1967) but there appears to be no contribution on its karyology from India except Sarma and Ramjee (1969) who have worked out the cytology of only one taxon viz. $T$. intricata f. prolifera. In the present investigation three taxa belonging to this genus viz. $T$. nidifica, $T$. nidifica var. nidifica f. stenhammariana and $T$. jwalai (sp. nov.) have been cytologically investigated.

\section{Material and methods}

Three taxa under study were collected from 2 districts of North Bihar viz. Gopalganj and West Champaran, details of which may be seen in the Table 1.

Table 1. Details of collection

\begin{tabular}{|c|c|c|c|c|}
\hline $\begin{array}{l}\text { S1. } \\
\text { no. }\end{array}$ & Name of the taxa & $\begin{array}{l}\text { Date of } \\
\text { collection }\end{array}$ & Place of collection & Habitat \\
\hline 1. & $\begin{array}{l}\text { Tolypella Leonh. nidifica } \\
\text { (O. Mill) A. Br., em. }\end{array}$ & $\begin{array}{l}\text { February } \\
1976\end{array}$ & $\begin{array}{l}\text { Bansibatranha, } \\
\text { Hathwa, Gopalganj }\end{array}$ & $\begin{array}{l}\text { Paddy } \\
\text { field }\end{array}$ \\
\hline 2. & $\begin{array}{l}\text { Tolypella nidifica var. nidifica } \mathrm{f} \text {. } \\
\text { stenhammariana (Walm in } \\
\text { lilj) R.D.W. }\end{array}$ & $\begin{array}{l}\text { February } \\
1979\end{array}$ & $\begin{array}{l}\text { Kumarbag, West } \\
\text { Champaran }\end{array}$ & $\begin{array}{l}\text { Paddy } \\
\text { field }\end{array}$ \\
\hline 3. & Tolypella jwalai sp. nov. & $\begin{array}{l}\text { February } \\
1976\end{array}$ & $\begin{array}{l}\text { Mishra Batranha, } \\
\text { Hathwa, Gopalganj }\end{array}$ & $\begin{array}{l}\text { Paddy } \\
\text { field }\end{array}$ \\
\hline
\end{tabular}

Cytological preparations were made from the antheridial filaments. Fixations of the healthy branches carrying sex organs were made on the collection spots between 8-10 A.M.

Carnoy's acetic-alcohol $(1: 3)$ was used as the fixative and iron-alum acetocarmine method (cf. Godwards 1948) was adopted throughout the study for cytological preparations.

The characteristics of the karyotype were worked out after ascertaining:

i) Length of the metaphase chromosomes.

ii) Total chromatin length as ascertained at metaphase.

iii) $\mathrm{TF} \%$ as per Huziwara (1962) i.e. 


$$
\mathrm{TF} \%=\frac{\text { Total sum of short arm length }}{\text { Total sum of chromosome length }} \times 100
$$

iv) Coefficient of variation (C.V.) as per following equation:

$$
\text { C.V. }=\frac{\text { Standard deviation }}{\text { Mean length of chromosome }} \times 100
$$

Cytological characters like chromosome number, $\mathrm{TF} \%$, coefficient of variation and total chromatin length were taken as the parameters for computing relative distances between the pairs of taxa at hand.

Relative distances between the taxa were computed through "Ordinary Euclidean" distance method (cf. Duran and Odell 1974). The equation of which may be read as follows:

$$
d_{i j}=\left[\sum_{K=1\left(X_{i K}-X_{j k}\right)^{2}}^{P}\right]^{1 / 2}
$$

where $\quad \mathrm{i}(\mathrm{j})=\operatorname{tax}$ on $(1,2,3 \cdots$ and $n)$

$d_{i j}=$ distance between ith and jth taxa

$P \quad=$ the number of cytological characters to be compared and

$\mathrm{X}_{\mathrm{IK}}=$ value of $\mathrm{K}$ th characters on ith taxa

The cluster analysis was performed in accordance with the Tocher's method (cf. Rao 1952).

The average within cluster distances were obtained by dividing the total within distance by the total number of pairs for each cluster thus formed. The average inter cluster distances among different pairs of taxa by the product of number of taxa in any pair of clusters.

\section{Cytological observation}

Karyological observation on three taxa viz. $T$. nidifica, $T$. nidifica var. nidifica f. stenhammariana and $T$. jwalai has revealed remarkable similarities as regards the organisation of nuclei and events of mitoses being on the pattern of other genera like Chara and Nitella. However, the overlapping of chromosomes at metaphase has been noted as a common feature in all the three taxa at hand which made correct counting of the chromosomes difficult.

Interphase nuclei, single nucleolus, which was constantly observed as dense spherical structure within the former and metaphase chromosomes have been carefully measured (cf. Table 2).

A count of 15, 11 and 6 chromosomes was ascertained at metaphase for $T$. nidifica (Fig. 1), T. nidifica var. nidifica f. stenhammariana (Fig. 2) and $T$. jwalai (Figs. 3 and 4) respectively. The length of two arms with respect to centromere has been measured and from this idiograms have been drawn (Figs. 5-7).

The total chromatin length, $\mathrm{TF} \%$ and coefficient of variation as computed for the karyotypes of three taxa under study have been summarised in the Table 3 along with respective chromosome number. 
Cluster analysis by distance suggests inclusion of $T$. nidifica and $T$. nidifica var. nidifica f. stenhammariana in one cluster having intra-cluster distance of 21.935 and T. jwalai in a separate cluster with inter-cluster distance of 129.011 (Fig. 8).

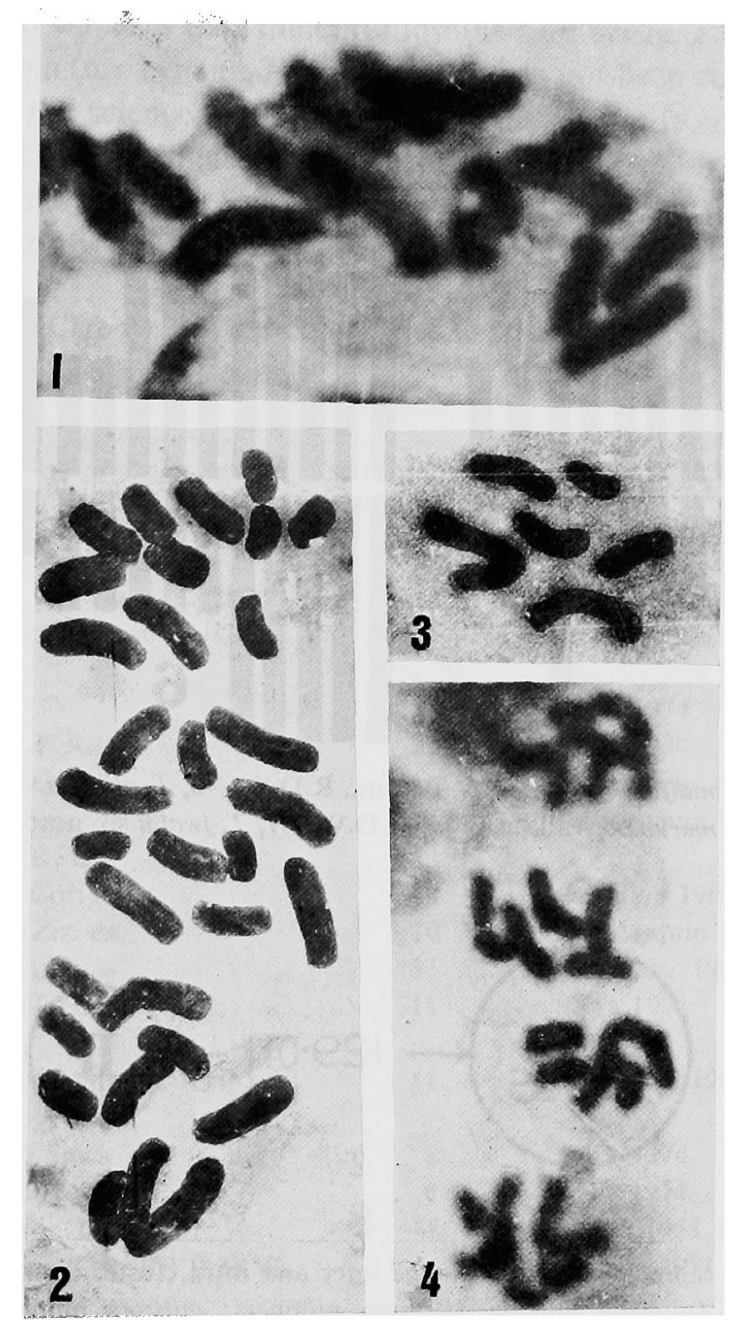

Figs. 1-4. 1, T. nidifica (O. Mill.) A. Br. em., R.D.W. $\mathrm{n}=15 . \quad \times 3200 . \quad 2$, T. nidifica var. nidifica f. stenhammariana (Wall. in Lilj.) R.D.W. three metaphase plates with $n=11 . \quad \times 3900 . \quad 3$ and 4, $T$. jwalai sp. nov. showing $\mathrm{n}=6$ at metaphase and at anaphase. $\times 3700$ respectively.

Table 2. Details of nuclei, nucleolus and range of chromosome length

\begin{tabular}{clccc}
\hline \hline $\begin{array}{l}\text { S1. } \\
\text { no. }\end{array}$ & Name of the taxa & $\begin{array}{c}\text { Diameter of } \\
\text { nuclei }(\mu \mathrm{m})\end{array}$ & $\begin{array}{c}\text { Diameter of } \\
\text { nucleoli }(\mu \mathrm{m})\end{array}$ & $\begin{array}{c}\text { Range of } \\
\text { chromosome } \\
\text { length }(\mu \mathrm{m})\end{array}$ \\
\hline 1. & $\begin{array}{l}T . \text { nidifica } \\
\text { T. nidifica var. nidifica } \mathrm{f} .\end{array}$ & $6.5-11.0$ & $1.76-2.2$ & $3.3-11.0$ \\
stenhammariana & $6.6-11.0$ & $1.76-2.64$ & $4.4-11.0$ \\
T. jwalai & $4.4-11.0$ & 2.2 & $2.2-6.6$ \\
\hline
\end{tabular}




\section{Discussion}

Variations in the diameter of nuclei and that of nucleoli among three taxa at hand have been recorded within the range merging in one another (cf. Table 2) and hence are of least taxonomic importance. Overlapping of long metaphase chromo-
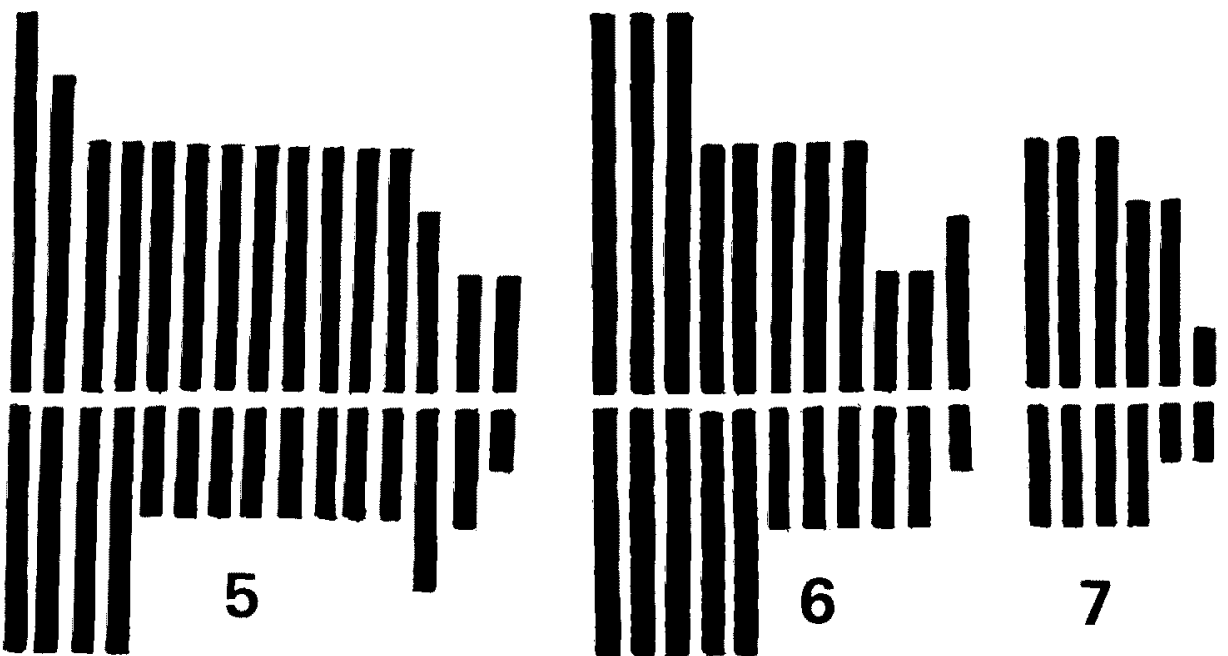

Idiograms 5-7. 5, T. nidifica (O. Miill.) A. Br. em., R.D.W. 6, T. nidifica var. nidifica f. stenhammariana (Wall. in Lilj.). R.D.W. 7, T. jwalai sp. nov.

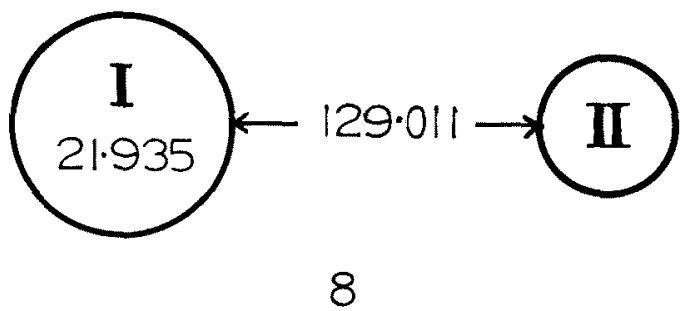

Fig. 8. Diagramatic representation of average inter and intra cluster distances between investigated three taxa of Tolypella Leonh. (Roman numbers: clusters number; Hindu numbers: intracluster distance). Cluster-I includes 1 and 2 and Cluster-II $T$. jwalai.

Table 3. Details of total chromatin length, $\mathrm{TF} \%$ and coefficient of variation

\begin{tabular}{clcccc}
\hline $\begin{array}{l}\text { S1. } \\
\text { No. }\end{array}$ & Name of the taxa & $\begin{array}{c}\text { Number } \\
\text { of } \\
\text { chromosome } \\
(\mathrm{n})\end{array}$ & $\begin{array}{c}\text { Total } \\
\text { chromatin } \\
\text { length } \\
(\mu \mathrm{m})\end{array}$ & TF\% & $\begin{array}{c}\text { Coefficient. } \\
\text { of variation }\end{array}$ \\
\hline 1. & $\begin{array}{l}\text { T. nidifica } \\
\text { T. nidifica } \text { var. nidifica } \mathrm{f} .\end{array}$ & 11 & 105.7 & 39.5 & 27.3 \\
Stenhammariana & & 85.6 & 40.0 & 35.1 \\
3. & 6 & 31.9 & 34.4 & 30.5 \\
\hline
\end{tabular}


somes observed by the authors is consistent with the report of Hotchkiss (1963, 1966).

The number of chromosomes has been ascertained as $\mathrm{n}=15$ for $T$. nidifica, $\mathrm{n}=$ 11 for $T$. nidifica var. nidifica f. stenhammariana and $\mathrm{n}=6$ for $T$. jwalai, From the available literature, it appears that the chromosome number in $T$. nidifica var. nidifica f. stenhammariana $(\mathrm{n}=11)$ and $T$. jwalai $(\mathrm{n}=6)$ has not been reported so far and so they are new to the science. Present count in $T$. nidifica $(n=15)$ is at variance with the report of Lindenbein (1927) who has reported $n=42$ for the same species.

The chromosome number reported so far in the taxa other than those worked out in the present study, is highly variable, ranging between 8 to 50 (cf. Table 4).

Table 4. Chromosome number reported so far in the taxa belonging to the genus Tolypella other than those investigated by the authors

\begin{tabular}{|c|c|c|c|}
\hline $\begin{array}{l}\text { S1. } \\
\text { No. }\end{array}$ & Name of the taxa & $\begin{array}{l}\text { Chromosome } \\
\text { number }(\mathrm{n})\end{array}$ & Worker's name and year \\
\hline 1. & T. hispanica Nordst. & 10 & Corillion and Guerlesquin 1959 \\
\hline 2. & T. hispanica var. Poteri Daily & 11 & Hotchkiss 1966 \\
\hline \multirow[t]{3}{*}{3.} & T. glomerata (Desv. in Lois) & 15 & Corillion and Guerlesquin 1959 \\
\hline & Leonh. & ca 20 & Guerlesquin 1964,1967 \\
\hline & & 33 & Sawa 1974 \\
\hline 4. & T. comosa T.F.A. & 33 & Sawa 1974 \\
\hline \multirow[t]{2}{*}{5.} & T. nidifica (O. Mill) & ca 42 & Lindenbein 1927 \\
\hline & $\begin{array}{l}\text { A. Br. Sub. Sp. } \\
\text { Occidentalis } \text { R. Cor. }\end{array}$ & ca 25 & Guerlesquin 1964 \\
\hline 6. & T. salina $\mathrm{R}$. Cor. & 50 & Corillion 1960 \\
\hline \multirow[t]{2}{*}{7.} & T. prolifera (Ziz. ex. & 10 & Guerlesquin 1961, 1967 \\
\hline & A. Br. Loenh.) & 11 & Hotchkiss 1966 \\
\hline 8. & $\begin{array}{l}\text { T. intricata (Trent. ex. Roth) } \\
\text { Leonh. }\end{array}$ & 11 & Sawa 1974 \\
\hline 9. & $\begin{array}{l}T \text {. intertexta (Trent. ex. Roth) } \\
\text { Leonh. }\end{array}$ & 11 & Hotchkiss 1966 \\
\hline 10. & T. canadensis Sawa & 8 & Sawa 1974 \\
\hline 11. & T. boldii Sawa & 8 & Sawa 1974 \\
\hline 12. & $\begin{array}{l}\text { T. intricata var. intricata f. } \\
\text { prolifera (Ziz. ex. A. Br) R.D.W. }\end{array}$ & 11 & $\begin{array}{l}\text { Sarma 1968, Sarma and } \\
\text { Ramjee } 1971\end{array}$ \\
\hline
\end{tabular}

Perusal of the chromosome counts in the Table 4 dose not permit consideration of any simple polyploid series in the genus. Probably due to this, there has been a controversy over the basic number of the genus Tolypella. While Hotchkiss (1966) has proposed 11 as the basic number of this genus, Guerlesquin $(1961,1967)$ has suggested the basic numbers 5 or 10 for its European species. Report of $n=33$ in two taxa (cf. Table 4) goes in favour of considering 11 as the basic number but the discovery of two lower counts viz. $n=6$ (present study) and $n=8$ (Sawa 1974) come in its way. However, a long polyploid series $(10,15,20,25$ and 50) in multiple of 5 may be visualised within the genus. In addition, two more possible polyploid series viz. $n=6$ and 42 and $n=11$ and 33 may also be seen. Therefore, if any effort is made to consider 5 and 11 as the basic number of the genus Tolypella, 6 and other 
unrelated count i.e. 8 deserve the same consideration. Sawa (1974) appears to be justified in deriving the different counts from the ancestral genome of 3-chromosome complement through aneuploidy at different levels of ploidy. Hotchkiss (1966) has also supported the derivation of $n=11$ from $n=12$ through the loss of one chromosome. Present count of $n=6$ in $T$. jwalai supports the existence of ancestral genome consisting of three chromosomes proposed by Sawa (1974). Different short polyploid series in the genus may be considered as an attempt towards establishment of distinct polyploid series in the tribe Chareae and Nitelleae.

The length of the chromosomes among three investigated taxa has been recorded between $2.2 \mu \mathrm{m}$ and $11.0 \mu \mathrm{m}$. There appears to be no previous record on the length of the chromosomes in this genus except Ramjee (1968) who has reported the range of chromosome length from 1.7 to $3.3 \mu \mathrm{m}$ in $T$. nidifica $\mathrm{f}$. prolifera.

Karyotype analysis in three species has revealed that in addition to chromosome number, they are distinct as regard the total chromatin length, $\mathrm{TF} \%$ and coefficient of variation among the chromosome complements (cf. Table 3). However, the aforesaid data do not throw any light on their phylogenetic relationship.

Adhering to the view of progressive evolution in Charophyta along with increase in the number of chromosomes (cf. Sarma et al. 1970 and Sawa 1973), T. jwalai possessing the lowest count $(\mathrm{n}=6)$ should be regarded as the most primitive and the rest two (having $\mathrm{n}=11$ and $\mathrm{n}=15$ ) as comparatively advanced. But $T$. jwalai with lowest total chromatin length and TF \% may be regarded as advanced than $T$. nidifica and $T$. nidifica var. nidifica f. stenhammariana. Even on the basis of coefficient of variation, $T$. jwalai keeps an intermediate position between the two. Similarly, $T$. nidifica var. nidifica $\mathrm{f}$. stenhammariana with $\mathrm{n}=11$ should be regarded as the primitive than $T$. nidifica with $\mathrm{n}=15$. But comparatively lower total chromatin length and higher coefficient of variation in the former points to its advancement over the latter. The sequential phylogenetic relationship can be expected only when there is unidirectional evolution. Unrelated features of primitiveness and advancement with different counts i.e. 6, 11 and 15 speak of their derivation along three independent lines of chromosomal differentiation in different time at different ploidy level.

\section{Acknowledgement}

Authors express their deep sense of gratitude to Dr. S. S. Prasad, Professor and Head, Department of Botany, University of Bihar, Muzaffarpur (Bihar) for providing laboratory facilities.

\section{Summary}

Three species of Tolypella Leonh. viz. 1, 2 and 3 have been cytologically investigated and their karyotypes have been worked out. The chromosome numbers in last two named taxa have been reported for the first time and hence are new to the science. In $T$. nidifica, present count is at variance with the previous report. Taxonomical distinction of taxa at hand has been discussed in the light of conclusions 
drawn from cluster analysis (by distance) on the basis of karyotypic data like chromosome number, total chromatin length, $\mathrm{TF} \%$ and coefficient of variation.

\section{References}

Corillion, R. 1960. Tolypella salina sp. nov., Charophycées nouvelle des macais de croix-de-vie (Vendee). Revue Algologique 5: 198-207.

- et Guerlesquin, M. 1959. Premières observations cytotaxonomiques sur genre Tolypella (Charophycées). Bull. Soc. et Sci. Angres. 2: 167-170.

Duran, B. S. and Odell, P. L. 1974. Cluster Analysis, A Survey. Springer-Verlag Berlin. Heidelberg, New York.

Guerlesquin, M. 1961. Contribution à l'étude chromosomique des Charophycées d'Europe Occidentale et d'Afrique du Nord. Rev. Gén. Bot. 68: 360-372.

- 1963. Contribution à l'étude chromosomique des Charophycées d'Europe Occidentale et d'Afrique du Nord. Ibid. 70: 354-370.

- 1964. Contribution à l'étude chromosomique des Charophycées d'Italie Péninsulaire. Ibid. 71: 283-292.

- 1967. Recherches caryotypiques et cytotaxonomiques chez les Charophycées d'Europe Occidentales et d'Afrique du Nord. Ph. D. Thesis (France).

Godward, M. B. E. 1948. The iron-alum acetocaramine method for Algae. Nature 161: 203.

Huziwara, Y. 1962. Karyotype analysis in some genera of Compositae. VIII. Further studies on the chromosomes of Aster. Amer. J. Bot. 49: 116-119.

Hotchkiss, A. T. 1963. A first report of chromosome numbers in Charophyte genus Lychnothamnus (Rupr.) Leonh. and comparison with the other Charophyte genera. Proc. Linn. Soc. New South Wales 138: 368-372.

- 1966. A new revised base chromosome number for the genus Tolypella. Bull. Torrey Bot. Club. 93: 426-432.

Lindenbein, W. 1927. Beitrag zur Cytologie der Charales. Planta 4: 436-466.

Rao, C. R. 1952. Advanced Statistical Methods in Biometric Research. John Wiley and Sons. New York.

Ramjee 1968. Contribution to the systematics, cytology and cytotaxonomy of Indian Charophyta. Ph. D. Thesis, B.H.U.

Sarma, Y.S. R. K. 1968. Cytology and cytotaxonomy of Indian Charophyta-A résumé. The Nucleus 11: 128-137.

- and Ramjee 1969. Chromosome numbers in three taxa of Indian Charophyta. J. Cytol. Genet. 4: 32-36.

- and - 1971. Significance of chromosome numbers in Charophyta-A discussion. Caryologia 24: $391-401$.

-, Khan, M. and Ramjee 1970. Cytological approach to phylogeny, inter-relationship and evolution in Charophyta. Indian Biologist 2: 11-19.

Sawa, T. 1974. New chromosome numbers for the genus Tolypella. Bull. Torrey. Bot. Club. 10: $21-26$. 